\title{
Grassroots prescriptivism
}

\author{
MORANA LUKA ̌
}

\author{
An analysis of individual speakers' efforts at maintaining \\ the standard language ideology
}

\section{Introduction}

People engage in discussions on which linguistic items are 'correct' and 'incorrect', 'acceptable' and 'unacceptable' on a daily basis. They do so in private conversations, but also publicly by way of telephone calls to radio stations, letters to newspapers and, since the dawn of the participatory internet, on social media platforms, such as blogs, microblogs (i.e. Twitter), forums and Facebook. Conspicuously, however, in linguists' theoretical models of language standardisation, speakers have traditionally been marginalised as passive followers of the norms established by language authorities. The types of discussions mentioned are viewed as having no impact on actual usage or on what it is that constitutes the standard variety, while standard language norms are, according to such accounts, enforced by language experts, codifiers and 'model speakers [such as journalists and newsreaders] and authors' (Ammon, 2015: 65).

Deborah Cameron is among the most prominent figures who challenged this strand of thought more than two decades ago in her influential book Verbal Hygiene (a term she uses to refer to prescriptivism). In doing so, she urged professional linguists to reconsider their perception of bottom-up prescriptive practices as 'irrelevant, futile and misguided' ([1995] 2012: vii). Linguists have since then continued to argue, from different perspectives, for the need to explore the role of language users in the process of standardisation (Hundt, 2009; Davies \& Zigler, 2015: 4). My own study which is part of the research project Bridging the Unbridgeable: Linguists, Prescriptivists and the General Public - is embedded in this proliferating field of research. In my analysis, I explore bottom-up prescriptive efforts of language users from all social backgrounds, which I refer to by the term 'grassroots prescriptivism'. Bottom-up or grassroots prescriptive efforts are here understood as those initiated by lay members of the general public, especially in contrast to top-down prescriptivism that is carried out institutionally. Whereas the most commonly explored prescriptive efforts are those initiated by official language institutions and authorities, grassroots prescriptivists wage their battles in the media by writing letters to newspaper editors, calling radio stations and engaging in online discussions on topics relating to usage. In shedding light on such practices, the analysis of discussions on linguistic features that speakers stigmatise such as the word literally to mean 'figuratively', and constructions such as between you and I instead of between you and me - proved to be a good starting point. Whereas it is fairly easy to identify where such discussions can be found, narrowing down all that is available to compile a collection suitable for analysis proved to be challenging. Nevertheless, the instances of metalinguistic discussions that I analysed in old and new media together with online

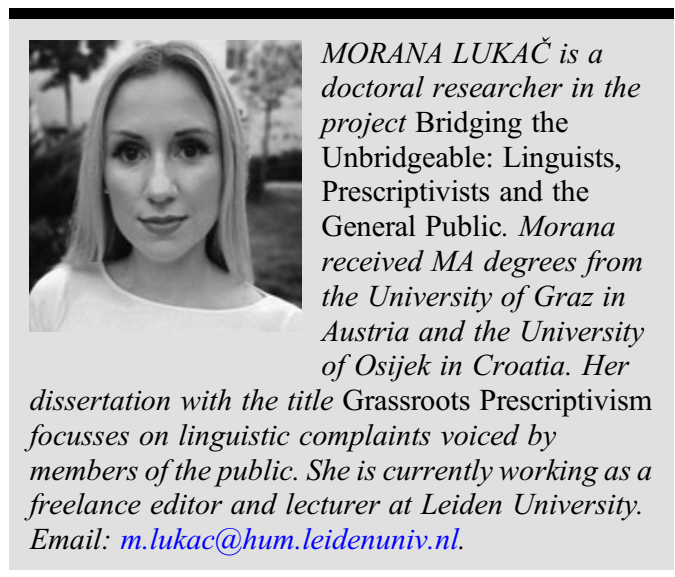


surveys in which people's practices of engaging in grassroots prescriptivism were investigated allowed me to explore, among other things, the following questions: Who are the people engaging in usage discussions? Which usage features are speakers particularly concerned about? Can we trace any changes regarding the features addressed in the debates? This paper describes the methodology employed in answering these questions and it offers provisional answers to them.

\section{Who complains about language use?}

People complaining about usage, whom I refer to as 'grassroots prescriptive activists', come from all walks of life. While we may expect older people to complain more often about linguistic decline, examples such as those of the 15 -year-old prescriptivist Albert Gifford prove such expectations wrong (Gifford, 2014). Gifford obliged Tesco to acknowledge a grammatical mistake in orange juice packaging (most tastiest instead of most tasty) and received a considerable amount of media coverage as a result. Prescriptive attitudes to language are also often viewed as being intertwined with conservative beliefs and political attitudes (Cameron, [1995] 2012: 9). Chapman (2012), however, demonstrates in his analysis of online complaints about the language of politicians in the US that linguistic prescriptivism wins most support from the political left in this country. He suggested that the supporters of the Democratic Party associate stigmatised linguistic features with a lack of education of conservative politicians. A recently published study by Boland and Queen (2016) states that sensitivity to linguistic errors, however, has little to do with traditional sociolinguistic categories (such as gender, age and level of education), but that it is rather related to personality traits. According to the two authors, less agreeable and more introverted people prove to be more sensitive to grammatical errors, and it may be such people who tend to voice their complaints.

Although Boland and Queen's study is informative as to what kind of people are more inclined to evaluate negatively authors of texts that contain linguistic errors, voicing complaints publicly is nevertheless a different matter altogether from critically evaluating language use in private. Not all people who are sensitive to errors become grassroots prescriptive activists and write letters to newspapers or engage in online discussions on grammar. To explore the social background of this group of people I searched through newspaper databases of The Times and The New York Times (NYT) for readers' letters containing linguistic complaints, which is where metalinguistic discussions are documented in the pre-internet age. Seeing that public discussions on language today are largely led online, I decided to widen the scope of the analysis and, together with Ingrid Tieken-Boon van Ostade, I launched an online survey in 2015 in which respondents were asked about their practices of publicly voicing complaints on usage both offline and online. The findings presented below aim to feed into wider debates about the participation in and the dynamics of grassroots prescriptivism.

\subsection{Letters to newspaper editors}

Both The Times and The NYT are quality daily newspapers ranking high in national circulation: seventh in the UK (Audit Bureau of Circulations, Mayhew, 2018) and second in the US (The Associated Press, 2013), respectively. Quality press, formerly referred to as 'broadsheet press' in the UK, is distinguished by the seriousness of the topics it addresses (including politics, economics and sports), and the higher education of its readers (cf. Bednarek, 2006: 13) when compared to popular press. I retrieved letters from both newspapers published during a four-month timespan (March-July) across a period of ten years, between 2000 and 2010. The search led to a collection of 105 letters from The Times (comprising 7,769 words) and 50 letters from The NYT (5,692 words). Although the two collections are not representative of either the language-related letters published in national newspapers of the two countries or even of the newspapers themselves, they nevertheless offer an insight into topics written in such letters and into the identity of their authors, who are required to sign their letters and who occasionally provide personal information as well. The following passage taken from a reader's letter published in The Times illustrates both the typical format and content of such letters:

(1) Sir, Full marks to Sir Jim Rose for at last acknowledging the importance of oral grammar in our education system. More than course work, teachers must be encouraged to correct incorrect grammar in the classroom. Not an easy task but a very necessary one. While going about this, perhaps they could help to discourage the use of the word like, with which most young people tend to preface each phrase. (The Times, 28 April, 2009, 25) 
The author, while referring to a previously published article, focuses on a particular grammatical feature - in this case the use of like as a discourse marker - and identifies 'most young people' as language offenders. Complaints like these frequently offer solutions to the perceived declining language standards, and this letter does so by urging teachers to correct their students' grammar.

Before analysing the letters themselves, I conducted interviews with a number of British journalists who engage in dialogue with the general public on matters of linguistic complaints to find out how they perceived grassroots prescriptivists. Oliver Kamm, the author of the language column The Pedant published in The Times, describes the grassroots prescriptivists as 'generally [...] people of an older generation who were taught "rules" at school and have been carrying these with them ever after' (personal communication, 6 May, 2015). Stephen Pritchard, who is the readers' editor of The Observer, adds that topics addressed in such letters reveal the older age of their writers (personal communication, 11 December, 2015). Gender, too, may play a role as to the identity of the people voicing the complaints, claims Ian Jolly, the BBC's chief style editor, who receives a large number of both emails and letters from the audience: 'If there's one thing I'd say they tend to be mostly men' (personal communication, 7 September, 2015). If we look at the gender of the authors of the letters that I collected, Jolly's judgment seems to hold true in this context as well. In both newspapers, males formed an overwhelming majority, with gender bias being lower in The NYT $(\mathrm{M}=$ $60 \%, \mathrm{~F}=34 \%)$ than in The Times $(\mathrm{M}=83.8 \%, \mathrm{~F}$ $=15.2 \%) .{ }^{1}$ People writing to the newspaper also occasionally identified themselves further by indicating their title or profession $(28 \%$ of The NYT and $18.1 \%$ of The Times letter writers), as indicated in Table 1 below.

Whereas professions mentioned included bankers and medical doctors, the majority of those who indicated what they did for a living were language professionals: English teachers, copy editors and professors of sociolinguistics. Although the people who wrote letters to the editor were not only lay members of the general public, but also language professionals (as many as $12.4 \%$ in The Times and $24.0 \%$ in The NYT), in their efforts the professionals too were engaging, I argue, in grassroots prescriptivism. They were contributing to public usage discussions instead of acting in their professional capacity. The contents of the letters written by language professionals indicated that in mentioning their skills and competence, the authors were attempting to gain distinction, lend credibility to the content of their letters and position themselves as experts in the public discussions on the readers' pages of the newspaper, as did this author of the following letter published in The NYT:

(2) As a teacher of English, a part-time poet and a full-time wordie, I took genuine delight in Patricia T. O'Conner's review of books about language by Ben Yagoda and David Crystal (1 April, 2007)2

By revealing their credentials, writers of letters such as the one in example (2) - appeal to what the sociologist Pierre Bourdieu calls 'cultural capital' (1986: 242), that is, to the knowledge that they have as members of the community of language professionals. It is this type of specific cultural capital that raises their status in usage debates and distinguishes them from lay participants.

\begin{tabular}{|c|c|c|c|c|c|c|c|c|}
\hline & \multicolumn{4}{|c|}{ Gender } & \multicolumn{4}{|c|}{ Language professional } \\
\hline & $\mathrm{M}$ & $\mathrm{F}$ & $\mathrm{U}^{*}$ & Total & Yes & No & $\mathrm{U}^{*}$ & Total \\
\hline The Times & 16 & 88 & 1 & 105 & 13 & 6 & 86 & 105 \\
\hline$\%$ & 15.2 & 83.8 & 0.9 & 100.0 & 12.4 & 5.7 & 81.9 & 100.0 \\
\hline The NYT & 17 & 30 & 3 & 50 & 12 & 2 & 36 & 50 \\
\hline$\%$ & 34.0 & 60.0 & 6.0 & 100.0 & 24.0 & 4.0 & 72.0 & 100.0 \\
\hline Total & & & & 155 & & & & 155 \\
\hline
\end{tabular}


This sociolinguistic overview of the letter writers, limited though it is, reveals two points that are relevant for my analysis of grassroots prescriptivism. First, males form a majority among them, which thus confirms the gender bias identified by Ian Jolly already referred to and the findings of earlier scholars who studied the genre (e.g. Wahl-Jorgensen, 2002: 184). Second, language professionals seem to dominate the discussions on usage among readers of the newspapers studied. This may be because they are more interested in the topic than lay readers or because their letters are selected more frequently by editors. Media scholars generally agree that letter pages are dominated by authors belonging to social elites: those who are more educated, wealthier and are considered to be authorities on the topic (Hart, 2001; Reader et al., 2004; Richardson, 2007). As useful a source on grassroots prescriptivism as the letters are, it needs to be noted that they form what are at best 'hazy reflections of the public opinion' (Grey \& Brown, 1970: 580). The voices of those otherwise belonging to the less influential social groups are, by contrast, not heard in traditional public forums and many of them may not decide to engage in discussions and write letters to begin with. This general observation translates into the more specific context of discussions on usage as well. Finally, I retrieved twice as many letters from the British than the American newspaper. This is a consequence of what I believe is a greater interest in the phenomenon among British readers. ${ }^{3}$ In my analysis of letters to the editor published across the English-speaking world (Lukač, 2016), I found that the practice of publishing letters on language use is not limited to a particular country. It is, however, the most popular in Australia and New Zealand, ${ }^{4}$ followed by Ireland and the UK, and least established in the US and in Canada.

\subsection{The survey}

Although letters to the editor may be among the oldest public media platforms, today they comprise only a fraction of public discussions on language: the liveliest arenas for such discussions can be found online. The survey which Ingrid TiekenBoon van Ostade and I created in order to find out whether and in what respect the participants of online discussions differ from those writing letters to newspapers was made available through the social media channels of the Bridging the Unbridgeable project between July and September 2015. It was completed by altogether 212 respondents, primarily university-educated $(93 \%)$ due to the channels through which we distributed it, ${ }^{5}$ who included both native (NS) (55.6\%) and nonnative (NNS) (44.4\%) speakers of English. Among the NSs, 55\% indicated their variety as British and $25 \%$ as American English, while for the NNSs, the most commonly chosen linguistic model was British English (47.4\%).

Very few respondents (16 out of the 174 who answered the question) confirmed that they had at some point in the past phoned in on a television or radio programme or written a letter to a newspaper in order to express their opinions on a particular linguistic feature. When compared with participation in online discussions (75/174), the difference is considerable: more people clearly engage in public discussions online than in traditional media, as the summary in Table 2 below goes to show. The reason for this is that there are fewer, if any, restrictions for doing so online; unlike newspaper editors, website moderators can often be bypassed, since the amount of filtering and selection of potentially undesirable content online varies considerably from website to website. On the whole, publishing has become effortless in the new media, at least for those living on the 'right' side of the digital divide. ${ }^{6}$

Moreover, the participants in online discussions tend to be younger than the writers of letters to the editor. (Only three out of 16 letter writers among the survey respondents were younger than 40.) Speakers aged under 40 are well acquainted with an environment in which opinions are shared publicly online, whereas older participants were used to expressing their views publicly decades ago only through letters and phone-ins. Digital debates are thus not only gaining ground, but those led in traditional media are also losing ground as forums for public discussion.

Table 2: 'Have you ever engaged in public discussions about language and grammar?'

\begin{tabular}{lcr|}
\hline Response categories & Frequency & $\%$ \\
\hline No & 74 & 42.5 \\
\hline Yes - online & 64 & 36.8 \\
\hline Yes - other & 20 & 11.5 \\
\hline $\begin{array}{l}\text { Yes - in both } \\
\text { traditional media and } \\
\text { online }\end{array}$ & 11 & 6.3 \\
\hline $\begin{array}{l}\text { Yes - in traditional } \\
\text { media }\end{array}$ & 5 & 2.9 \\
\hline Total & 174 & 100.0 \\
\hline
\end{tabular}


Nevertheless, the participation in usage debates is not equal in the seemingly more democratic online platforms. NNSEs were found to be less likely to engage in usage discussions - only 45 per cent of the NNSs who completed the survey had ever taken part in any public discussions on usage in contrast to 68 per cent of NSs - and when they do so, their comments do not centre around usage features in English, but rather on their own native languages. Arguably feeling that they lack the linguistic capital associated with NSs, NNSs feel less confident in commenting on other people's usage in English, and, as a consequence, they form a less powerful group in interactions on usage compared to NSs. This stands in stark contrast with the fact that the number of NNSs of English is far greater than that of NSs. According to Crystal's estimates in English as a Global Language, in 2003 (p. 69), NNSs outnumbered NSs by 3 to 1, and in an interview he gave in $2014,{ }^{7}$ he claimed that, with the number of NNSs steadily rising, the ratio has changed to 5 to 1. NNSs nevertheless remain on the periphery of usage debates, as the 2015 survey confirmed. My comments here are provisional, and further research is yet to reveal what roles NNSs play in debates on usage.

\section{Which linguistic features are stigmatised in public discussions on usage?}

\subsection{Comparing The Times and The New York Times}

Analysing letters to the editor from a US-American and a British newspaper allowed for a comparison between the linguistic complaints in the two countries. Regardless of the variety, among the lay community word choice is the central topic in usage discussions. Not only in newspapers, but also online, we can observe the importance placed on lexical choice in the numerous lists disseminated on social media featuring 'misused' words (e.g. '32 Incorrectly Used Words that Make You Look Bad' and ' 25 Common Words That You've Got Wrong') (cf. Vriesendorp, 2016). Such lists seemingly outnumber sites providing online advice on grammar, spelling and pronunciation. The specific lexical items that are addressed in the complaints, however, differ between the two countries: corruption by Americanisms permeates the letters in the British broadsheet that warn against '[British English] rapidly disappearing and being replaced with American English, usually for no good reason' (The Times, 9 June, 2009: 25). For the Times readers, the link between lexical choice and nationality thus takes centre stage. They, moreover, seem to advocate a culturally homogenous version of British English purified from outside influences (which they identify as primarily coming from across the Atlantic). On the other hand, political correctness constitutes the central topic in the American newspaper, as example (3) goes to show.

(3) Why do you refer to Mr. Young as Mr. Sullivan's 'partner' rather than his spouse? Using the former term tends to suggest that married same-sex couples are somehow less married than their different-sex counterparts, whom you would never call 'partners'. (NYT, 4 May, 2007)

Complaints such as this one can be categorised under what Curzan (2014: 24) in her taxonomy calls 'politically responsive' prescriptivism, which 'aims to promote inclusive, nondiscriminatory, politically correct, and/or politically expedient usage'. In challenging a journalist's lexical choice (partner vs. spouse), the writer of this letter champions political correctness, a movement that has perhaps had an overall greater linguistic effect in the US than in the UK (Nagle, Fain \& Sanders, 2000: 257; Hughes, 2010: 64), which accounts for the relative rarity of the topic in the letters from The Times.

The differences between the complaints from the two newspapers are not confined to the realm of lexis. The list of topics addressed per linguistic level, as well as examples of usage features, are included in Tables 3 and 4 below. British and American letter writers differ in their treatment of accent and other phonological features as well. Striking here is the difference in the frequency with which these topics are addressed. While British writers criticise the BBC presenters for mistakes in their pronunciation and express concerns regarding the high rising intonation in declarative sentences that is popularly called 'upspeak', phonology seems to remain for the most part unaddressed among the American letter writers. Such a difference is in line with Leslie Milroy's claim that standardness is perceived differently in the two varieties: 'popular perceptions involve accent in Britain but not in the United States, where standardness appears to be essentially the avoidance of particular socially marked grammatical and lexical systems' (Milroy, 2001: 58).

Letters addressing nonstandard spelling found in computer-mediated communication (CMC) reveal 
Table 3: Complaints per linguistic level in The Times letters

$\begin{aligned} & \text { Linguistic } \\ & \text { level }\end{aligned}$
$\begin{aligned} & \text { Lexis } \\ & \text { 28 }\end{aligned}$

\section{Table 4: Complaints per linguistic level in The NYT letters}

\begin{tabular}{|c|c|c|}
\hline $\begin{array}{l}\text { Linguistic } \\
\text { level }\end{array}$ & $\%$ & Examples of usage features \\
\hline Lexis & 55 & $\begin{array}{l}\text { inclusive language (black/coloured/African-American; partner/spouse); jargon } \\
\text { (medicine: brain dead; business: vision; mission); political euphemisms } \\
\text { (extraordinary rendition) }\end{array}$ \\
\hline Morphology & 6 & $\begin{array}{l}\text { CMC neologisms (delinquency }+ \text { link }>\text { delinkquency "opting out of Web } \\
\text { communication"; cellphone }+ \text { celibacy }>\text { cellibacy "opting out of cellphones") }\end{array}$ \\
\hline Orthography & 20 & CMC (abbreviations); misplaced apostrophes \\
\hline Phonology & 1 & native and non-native speaker accent \\
\hline Syntax & 7 & split infinitives (to carefully scrutinize); dangling modifiers \\
\hline
\end{tabular}

an overarching moral panic in the period between 2000 and 2010 on both sides of the Atlantic. This is exemplified by this letter whose author adopts a caricatured style of $\mathrm{CMC}$, which is commonly found in letters on the topic:

(4) i am a writing tutor, and i have noticed that a number of hi school students are now writing formal papers in much the same style as they use on the net - in other words, w/plenty of abbreviations, not alot of regard for punctuation, and most of all, virtually no capitalization. it is an uphill battle to get them to understand that essay writing is not the same as email. (NYT, 16 March, 2000)

The alarmist tone surrounding CMC expressed here is not unexpected given the newness of the phenomenon at the time. Worries expressed by the writing tutor in (4), however, have been proven unjustified by a number of studies that showed that CMC in fact constitutes a positive factor in literacy (Plester, Wood \& Joshi, 2009; Wood et al., 2011). In spite of the recurring complaints among members of the public, according to researchers, (young) users of digital technologies are as a rule able to adapt their writing style to different contexts after all.

Whereas lexical choice and spelling conventions comprise the most salient topics of linguistic criticism in the letters analysed, finer points related to deeper syntactic structures of the language generally appear to escape the eyes of the lay observers. When grammar is taken up in the discussions, the features addressed include long-established and widely discussed usage items, such as double negation, the use of subject pronouns instead of objective forms ( $I$ for $m e$ ), and split infinitives (forms in which a word or a phrase is inserted between the 
infinitive marker to and the verb form). Letter writers as a rule note few new developments in the grammatical system, if any at all. ${ }^{9}$

\subsection{The survey}

Although the readers' letters and the online survey were analysed separately and were not originally envisaged as comparative studies, several interesting differences emerged as to the usage-related topics that the letter writers and survey respondents identified. Some of the differences can be ascribed to the fact that the respondents reported discussing usage predominantly online, rather than in the old media. For them, orthographical mistakes were the main point of concern and the examples cited were often found in the context of the social media:

(5) Someone had misspelled 'dibs' for 'dips' in a Facebook post. I thought the mistake was a bit silly. (male, NS, aged 25-40)

Written language is foregrounded in the online environment, and consequently, orthography may be the topic of main concern, while grammatical, that is, traditional, usage problems are fading into the background (cf. Vriesendorp, 2016).

In contrast to the letter writers analysed, the survey respondents, who were younger (from what I can tell based on the demographic data available for letter writers) and many of whom had a background in linguistics, exhibited more tolerant views of language variation and change.

(6) I'm a linguist so I often participate in such discussions, although I almost never come down on the prescriptive side ;-). (female, NS, aged 25-40)

(7) I wasn't complaining; I was defending (being a lexicographer) (female, NS, aged 50-65)

As opposed to the respondents who expressed prescriptive attitudes, those who identified themselves as 'linguists' (as in 6) and 'lexicographers' (in 7) report not being annoyed by usage problems themselves, but rather by complaints about usage.

\section{Conclusion}

Whereas usage debates can be found in all types of media and complaints come from people of varying backgrounds, participation in discussions on usage is not egalitarian. In the old media, such as newspapers, public forums largely reflect the opinions of males and the highly educated, and in the new media, with all its promises of democratic participation, divisions continue to exist between NSs and NNSs, with the latter group being largely absent from the discussions. Descriptivism and tolerant views of language - based on the results of the survey presented - are championed across all age groups. The most significant variable that seems to influence the attitudes of the survey participants towards problematical usage features is an education in linguistics and an understanding of linguistic variation and change. ${ }^{10}$

Topics of usage discussions were found to vary depending on the context in which these discussions are held. They point to cultural differences if we compare the debates held on the letter pages of British and American newspapers, as well as to the nature of the different media. Orthography, the most superficial linguistic level, is currently taking centre stage in the digital environment. The findings of the two studies presented here reveal that the differences and the changes in the ongoing usage debates and the topics they address remain indicative of the social environments in which they are embedded and the linguistic ideologies associated with them.

\section{Notes}

1 In all but four letters in my collection where the name was either gender-neutral or only the initials were provided, it proved possible to determine the gender of the author.

2 Bold type is used for emphasis throughout this paper. 3 The difference in the number of published letters to the editor may also be partly explained by the fact that The NYT had already dedicated a section to language use in its On Language column in the period between 1979 and 2009, which largely coincided with the period covered in my collection. In comparison, The Times started featuring its language column The Pedant only in 2009.

4 The number of letters on usage published in Australia and New Zealand can perhaps be explained by the factor Burridge and Severin (2017) refer to as 'cultural cringe', or an internalised inferiority complex. Antipodean grassroots prescriptivists fear that the 'decaying standards' they identify reveal that theirs is a stigmatised variety of English. To protect their variety from further decline, the writers believe that proper standards need to be fiercely defended (Severin, personal communication, 22 November, 2016).

5 Since the responses were not obligatory, the percentages indicated are relative to the number of people who provided an answer to the indicated question.

6 According to the website Internet World Stats, currently $51.7 \%$ of the world population are internet users <http://www.internetworldstats.com/stats.htm.> (Accessed September 18, 2017).

7 The interview is available at $<$ https://teflequityadvocates.com/2014/07/06/interview-with-david-crystal/> (Accessed September 18, 2017). 
8 High Rise Terminal denotes high rising intonation in declarative sentences popularly referred to as 'uptalk'. 9 Mair (2006) makes a similar observation in Twentieth-Century English. According to him, anecdotal observations of language change often illustrate 'a minor lexical recategorisation within a stable grammatical system' instead of reflecting 'far-reaching and systematic change in grammatical rules and patterns' (2006: 17).

10 For a detailed discussion on the relevance of age and education in accounting for linguistic attitudes, see Severin (2017).

\section{References}

Ammon, U. 2015. 'On the social forces that determine what is standard in a language - with a look at the norms of non-standard language varieties.' Bulletin VALS-ASLA, 3, 53-67.

The Associated Press. 2013. 'Top 10 newspapers by circulation: Wall Street Journal leads weekday circulation.' The Huffington Post, April 30, 2013.

Vriesendorp, H. 2016. 'The Internet's (New) Usage Problems.' English Today, 32(3), 18-19.

Bednarek, M. 2006. Evaluation in Media Discourse: Analysis of a Newspaper Corpus. New York and London: Continuum.

Boland, J. E. \& Queen, R. 2016. 'If you're house is still available, send me an email: Personality influences reactions to written errors in email messages.' Plos One, 11(3). Online at $<$ http://journals.plos.org/> (Accessed July 6, 2017).

Bourdieu, P. 1986. 'The forms of capital.' In J. Richardson (ed.), Handbook of Theory and Research for the Sociology of Education, New York: Greenwood Press, pp. 241-56.

Burridge, K. \& A. Severin. 2017. 'What do "little Aussie Sticklers" value most?' Paper presented at the conference Value(s) and Language Prescriptivism, Brigham Young University, Utah, 2017.

Cameron, D. 2012. Verbal Hygiene: The Politics of Language (rev. edn.) London \& New York: Routledge.

Chapman, D. 2012. 'You say nucular; I say yourstupid: Popular prescriptivism in the politics of the United States.' In C. Percy \& M. C. Davidson (eds), The Languages of Nation: Attitudes and Norms. Bristol, Buffalo and Toronto: Multilingual Matters, pp. 192-207.

Crystal, D. 2003. English as a Global Language (2 ${ }^{\text {nd }}$ edn.) Cambridge: Cambridge University Press.

Curzan, A. 2014. Fixing English: Prescriptivism and Language History. Cambridge: Cambridge University Press.

Davies, W. V. \& Ziegler, E. (eds.) 2015. Language Planning and Microlinguistics: From Policy to Interaction and Vice Versa. Basingstoke and New York: Palgrave Macmillan.

Gifford, A. 2014. 'Why I, a 15-year-old grammar pedant, took on Tesco.' The Guardian, June 19. Online at <https:// www.theguardian.com> (Accessed July 6, 2017).
Grey, D. L. \& Brown, T. 1970. 'Letters to the editor: Hazy reflections of public opinion.' Journalism Quarterly, 47, 450-56.

Hart, R. P. 2001. 'Citizen discourse and political participation: A survey.' In W. L. Benett \& R. M. Entman (eds.), Mediated Politics: Communication in the Future of Democracy. Cambridge: Cambridge University Press, pp. 407-32.

Hughes, G. 2010. Political Correctness: A History of Semantics and Culture. Malden, MA: Wiley-Blackwell.

Hundt, M. 2009. 'Normverletzungen und neue Normen.' In M. Knopka \& B. Strecker (eds.), Deutsche GramatikRegeln, Normen, Sprachgebrauch. Berlin: de Gruyter, pp. $117-40$.

Lukač, M. 2016. 'Linguistic prescriptivism in letters to the editor.' Journal of Multilingual \& Multicultural Development, 37(3), 321-33.

Mair, C. 2006. Twentieth-Century English. Cambridge: Cambridge University Press.

Mayhew, F. 2018. 'National newspaper print ABCs: Daily Star overtakes Daily Telegraph for first time in over a year + full figures for Jan.' Press Gazette, February 15. Online at $<$ https://www.pressgazette.co.uk/national-newspaper-printabcs-daily-star-overtakes-daily-telegraph-for-first-time-inover-a-year/> (Accessed 3 September 2018).

Milroy, L. 2001. 'Britain and the United States: Two nations divided by the same language (and different language ideologies).' Journal of Linguistic Anthropology, 10(1), 56-89.

Nagle, S. J., Fain, M. A. \& Sanders, S. L. 2000. 'The influence of political correctness on lexical and grammatical change in late-twentieth century English.' In D. Kastovsky \& A. Mettinger (eds.), The History of English in a Social Context: A Contribution to Historical Sociolinguistics. Berlin and New York: Mouton de Gruyter, pp. 257-77.

Plester, B., Wood, C. \& Joshi, P. 2009. 'Exploring the relationship between children's knowledge of text message abbreviations and school literacy outcomes.' British Journal of Developmental Psychology, 27(1), 145-61.

Reader, B., Stempel, G. \& Daniel, D. 2004. 'Age, wealth and education predict letters to the editor.' Newspaper Research Journal, 25(4), 55-66.

Richardson, J. E. 2007. Analysing Newspapers: An Approach from Critical Discourse Analysis. Basingstoke: Palgrave Macmillan.

Severin, A. A. 2017. 'Vigilance or tolerance? Younger speakers' attitudes to Australian English usage.' Australian Journal of Linguistics, 37(2), 156-81.

Wahl-Jorgensen, K. 2002. 'The construction of the public in letters to the editor: Deliberative democracy and the idiom of insanity.' Journalism, 3(2), 183-204.

Wood, C., Jackson, E., Hart, L., Plester, B. \& Wilde, L. 2011. 'The effect of text messaging on 9- and 10-year-old children's reading, spelling and phonological processing skills.' Journal of Computer Assisted Learning, 27, 28-36. 